\title{
Improvement of mouse cloning using nuclear transfer-derived embryonic stem cells and/or histone deacetylase inhibitor
}

\author{
SAYAKA WAKAYAMA and TERUHIKO WAKAYAMA* \\ Riken Center for Developmental Biology, Kobe, Japan
}

\begin{abstract}
Nuclear transfer-derived ES (ntES) cell lines can be established from somatic cell nuclei with a relatively high success rate. Although ntES cells have been shown to be equivalent to ES cells, there are ethical objections concerning human cells, such as the use of fresh oocyte donation from young healthy woman. In contrast, the use of induced pluripotent stem (iPS) cells for cloning poses few ethical problems and is a relatively easy technique compared with nuclear transfer. Therefore, although there are several reports proposing the use of ntES cells as a model of regenerative medicine, the use of these cells in preliminary medical research is waning. However, in theory, 5 to 10 donor cells can establish one ntES cell line and, once established, these cells will propagate indefinitely. These cells can be used to generate cloned animals from ntES cell lines using a second round of NT. Even in infertile and "unclonable" strains of mice, we can generate offspring from somatic cells by combining cloning with ntES technology. Moreover, cloned offspring can be generated potentially even from the nuclei of dead bodies or freeze-dried cells via ntES cells, such as from an extinct frozen animal. Currently, only the ntES technology is available for this purpose, because all other techniques, including iPS cell derivation, require significant numbers of living donor cells. This review describes how to improve the efficiency of cloning, the establishment of clone-derived embryonic stem cells and further applications.
\end{abstract}

KEY WORDS: clone, nuclear transfer, reprogramming, ntES cell

\section{Introduction}

Since it was first reported in 1997 that a sheep had been cloned (Wilmut et al., 1997), more than 10 additional mammalian species have been cloned successfully using somatic cell nuclear transfer (SCNT). While cloning efficiencies can range from $0 \%$ to $20 \%$, efficiency rates of only $1 \%-2 \%$ are typical for mice. Moreover, many abnormalities in mice cloned from somatic cells have been reported, including abnormal gene expression in embryos (Boiani et al., 2002; Bortvin et al., 2003; Kishigami et al., 2006a; Inoue et al., 2010), abnormal placentas (Tanaka et al., 2001; Wakayama and Yanagimachi, 1999), obesity (Tamashiro et al., 2002; Tamashiro et al., 2000), early death (Ogonuki et al., 2002) and sex reversal (Inoue et al., 2009). Such abnormalities notwithstanding, success in generating cloned offspring has still opened new avenues of investigation.

Recently, we found that the efficiency of mouse cloning could be enhanced up to fivefold through the addition of the histone deacetylation inhibitor trichostatin A (TSA) into the oocyte activation medium (Kishigami et al., 2006b), even though high concen- trations of TSA are toxic to embryonic development (Svensson et al., 1998). This result suggests that nuclear reprogramming might be enhanced by chemical treatment and that this method will provide a new approach for practical improvements in mouse cloning techniques and new insights into the genomic reprogramming of somatic cell nuclei. However, the success rate of producing cloned offspring is still too low to apply for practical purposes such as for agriculture or industry. Moreover, this modified method can be used only for 'clonable' strain donor cells from particular strains or cell types. In the mouse, most strains cannot be used to generate cloned offspring, even with the use of TSA. In addition, live donor cells are required for SCNT. It was thought that even extinct species could be resurrected by SCNT from frozen cells, but it is almost impossible to apply current SCNT technology for this purpose.

Abbreviations used in this paper: ES, embryonic stem cell; HDACi, histone deacetylase inhibitor; ntES, nuclear transfer-derived ES cell; SCNT, somatic cell nuclear transfer; TSA, trichostatin A.

\footnotetext{
*Address correspondence to: Teruhiko Wakayama. Riken Center for Developmental Biology, 2-2-3 Minatojima-minamimachi, Kobe 650-0047, Japan. Fax: 81-78-306-0101. e-mail: teru@cdb.riken.jp 
On the other hand, it is known that embryonic stem (ES) cell lines can be established from cloned embryos. The first success in generating ES-like cell lines by SCNT was initially performed in the bovine (Cibelli et al., 1998) and then subsequently in the mouse (Kawase et al., 2000; Munsie et al., 2000). We have shown previously that these ES-like cell lines are capable of differentiating into all three germ layers in vitro, or even into spermatozoa and oocytes in chimeric mice (Wakayama et al., 2001). This was the first demonstration that such ES-like cells have the same potential as ES cells from fertilized blastocysts. To distinguish NT-derived ES cell lines from those lines derived from fertilized embryos, the former are referred to as ntES cell lines (Wakayama et al., 2001). Interestingly, such ntES cell lines can be established with success rates 10 times higher than from 'conventional' reproductive cloning (Fig. 1) (Wakayama et al., 2006; Wakayama et al., 2005b; Wakayama et al., 2005c; Wakayama et al., 1998; Wakayama et al., 2001). Although almost all of the cloned mice showed some abnormalities and ntES cells were established using the same NT procedure, ntES cells are transcriptionally and functionally indistinguishable from the ES cells derived from fertilized embryos (Brambrink et al., 2006; Wakayama et al., 2006).

Unfortunately, human ntES cells pose ethical problems because fresh oocytes must be donated by healthy women and the resulting cloned embryos are deprived of their potential to develop into a complete human being. Therefore, although there are several reports proposing the use of human ntES cells as a model of regenerative medicine (Rideout et al., 2002; Tabar et al., 2008), the use of these cells in preliminary medical research is waning. However, for basic biology, the ntES cell techniques can be applied to characterize very rare and specialized cell types in the body, such as olfactory neurons. In theory, 5 to 10 donor cells can establish one $\mathrm{ntES}$ cell line and, once established, these cells will propagate indefinitely.

In this review we will describe another use of ntES cells, which is to generate cloned animals from ntES cell lines using a second round of NT (Thuan et al., 2010; Wakayama, 2007; Wakayama et al., 2001). Even in infertile and 'unclonable' strains of mice, we

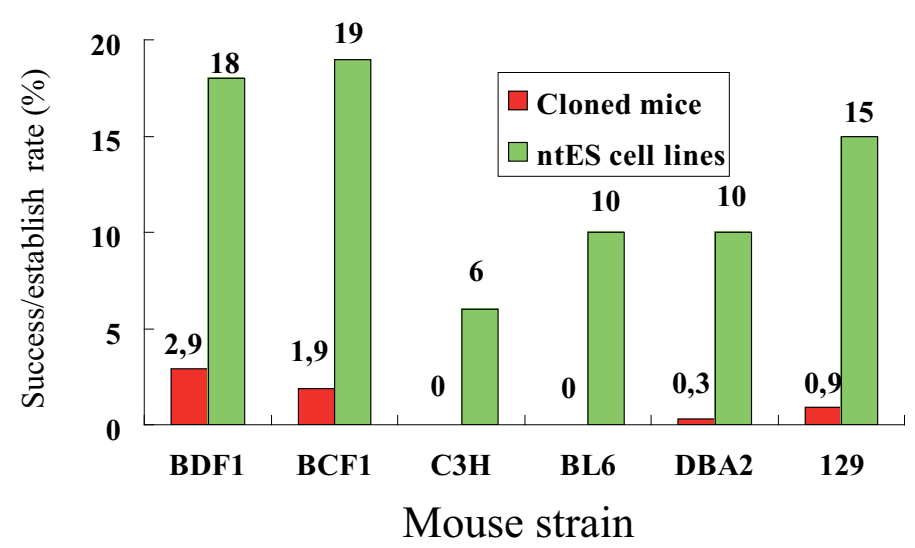

Fig. 1. Comparison of the success rate of cloned mice and establishment rate of nuclear transfer-derived embryonic stem (ntES) cell lines. The rate of ntES cell establishment is nearly 10 times higher than the rate of producing cloned mice. Interestingly, ntES cell lines can be established even from 'unclonable' mouse strains, such as $\mathrm{C} 3 \mathrm{H}$ or C57BL/6 (BL6). can generate offspring from somatic cells by combining cloning with ntES technology (Mizutani et al., 2008; Wakayama et al., 2005a; Wakayama et al., 2005b). Moreover, cloned offspring can be generated potentially even from the nuclei of dead bodies or cells (Ono et al., 2008; Wakayama et al., 2008), such as from frozen extinct animals. Currently, only the ntES technology is available for this purpose, because all other techniques, including induced pluripotent stem (iPS) cell derivation, require significant numbers of living donor cells.

\section{New attempts to improve the efficiency of mouse clon- ing}

Before we start to describe ntES cell technology, we will introduce our recent progress in increasing the success rate of mouse cloning using chemical treatments such as the use of histone deacetylase inhibitors (HDACi). We previously reviewed many different approaches to improve the efficiency of mouse cloning (Wakayama, 2007), but most of those methods had no effect on the overall success rate. However, nearly 10 years ago we accidentally discovered that $1 \%$ DMSO could significantly improve the frequency of development to the blastocyst stage in vitro (Wakayama and Yanagimachi, 2001a). Although it is not clear why DMSO enhanced the developmental potential of cloned embryos, it was the first demonstration that nuclear reprogramming can be enhanced artificially using chemical treatment.

\section{Epigenetic alterations by chemical treatment}

As mentioned above, a recent molecular analysis of cloned embryos revealed abnormal epigenetic modifications such as aberrant DNA methylation and histone modification (Dean et al., 2001; Kang et al., 2001; Ohgane et al., 2001; Santos et al., 2003). Therefore, the prevention of epigenetic errors is expected to improve the success rate of animal cloning. Recently, Iwatani et al. discovered that DMSO treatment affects DNA methylation status at multiple loci (Iwatani et al., 2006). DMSO probably enhances the epigenetic reprogramming of cloned embryos during in vitro culture. Enright et al. have tried to alter the epigenetic status of donor nuclei used for bovine cloning by using two chemicals: 5-azacytidine, an inhibitor of DNA methylation and TSA, an HDACi (Enright et al., 2003). Although the in vitro developmental potential was increased significantly with TSA, the cells did not demonstrate full-term development. Because those epigenetically affecting drugs are very toxic (Gurvich et al., 2005; Kishigami et al., 2006c), each drug must be tested pharmacologically for its appropriate exposure, timing, concentration and duration.

Discovery of the optimal HDACi treatment for mouse cloning

In this situation, Kishigami et al. discovered by trial and error the optimum concentration, timing and period of TSA treatment for cloning mouse embryos. Eventually this method led to a greater than fivefold increase in the success rate of mouse cloning and a doubling in the rate of establishing ntES cell lines using cumulus cell, tail fibroblast, neural stem cell and spleen cell (Kishigami et al., 2006b). These results were independently and concurrently corroborated by Tsunoda's laboratory (Rybouchkin et al., 2006), showing that the effects of TSA are reproducible. On the other hand, most cloned mice have only been generated from 


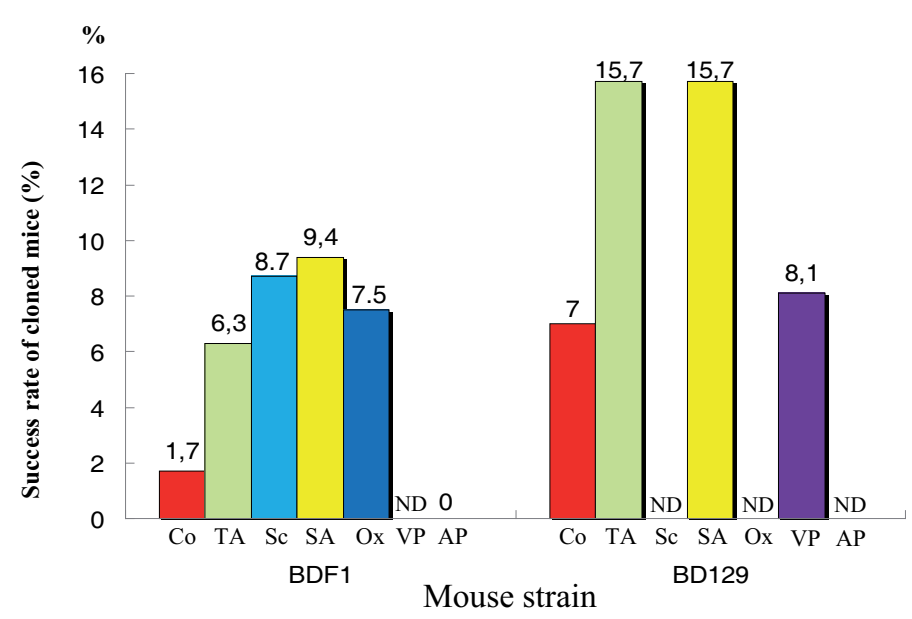

Fig. 2. Effects of histone deacetylase inhibitor (HDACi) treatment on mouse cloning. Without HDACi treatment, cloned mice could be obtained but with a low success rate. When trichostatin A (TSA), scriptaid $(S C)$, suberoylanilide hydroxamic acid (SA) or oxamflatin (Ox) were used, the success rates were increased with both BDF1 and BD129F1 strains; however, when valproic acid (VPA) or aroyl pyrrolyl hydroxamide (AP) were used, the overall success rate was not increased.

hybrid strains and have never been cloned from outbred or inbred strains (Inoue et al., 2003; Wakayama and Yanagimachi, 2001b). Although we found that TSA could be used to produce cloned mice even from an outbred supposedly 'unclonable' strain (Kishigami et al., 2007), most of the important mouse strains have never been cloned successfully.

Although TSA treatment resulted in great improvements in SCNT cloning in mice, its effects on cloning efficiency are controversial for the bovine (lager et al., 2008; Wu et al., 2008), pig (Li et al., 2008; Yamanaka et al., 2009), rabbit (Meng et al., 2009; Shi et al., 2008) and rat (Sterthaus et al., 2009). Moreover, some groups have reported that TSA treatment had detrimental effects on the in vitro and in vivo development of SCNT embryos (Meng et al., 2009; Wu et al., 2008). To our knowledge, the effects of TSA treatment on full-term development have not been determined in any species other than the mouse. In experiments on rabbits, all cloned offspring treated with TSA died within 19 days after birth, whereas the untreated control clones grew to adulthood (Meng et al., 2009). On the other hand, it is known that the drug scriptaid acts as an HDACi, but is less toxic than TSA (Su et al., 2000). Using this drug, Zhao et al. improved the success rate of pig cloning to full term (Zhao et al., 2009). At the same time, Van Thuan et al. found that scriptaid treatment could increase cloned embryo development rates not only in hybrid but also in inbred strains of mice and this allowed us to generate full-term offspring from several inbred strains, such as C57BL/6 and C3H/He (Van Thuan et al., 2009). These results suggest that although the use of HDACi drugs can enhance reprogramming in cloned embryos, because of their toxicity, the effects depend on the sensitivity of the donor strain or species. More recently, we found that two other specific HDACi agents, suberoylanilide hydroxamic acid (SAHA) and oxamflatin, could also improve the full-term development of cloned mice and establishment of ntES cell lines significantly without leading to obvious abnormalities (Ono et al., 2010). Another group found that $m$-carboxycinnamic acidbishydroxamide
(CBHA) also improve the full-term mouse cloning(Dai et al., 2010). However, although valproic acid (VPA) was reported to increase the reprogramming efficiency of mouse fibroblasts by more than 100-fold to establish induced pluripotent stem cells (Huangfu et al., 2008), it had little (Costa-Borges et al., 2010) or no effect (Ono et al., 2010) on the success rate of mouse cloning. Another inhibitors, aroyl pyrrolyl hydroxamide (APHA), also could not improve cloning efficiency (Van Thuan et al., 2009). Fig. 2 summarized the effect of HDACis on mouse cloning between BDF1 and BD129F1 cumulus cells (Kishigami et al., 2006b; Ono et al., 2010; Van Thuan et al., 2009).

\section{Which HDAC has a negative effect on nuclear repro- gramming?}

In general, the HDAC enzymes are divided into five categories: class I (HDAC 1, 3 and 8), class Ila (HDAC 4, 5, 7 and 9), class IIb (HDAC 6 and 10), class III (SIRT1 to 7) and class IV (HDAC 11) (Blackwell et al., 2008). As shown in Table 1, so far seven classes of HDACi have been examined in our laboratory. TSA, scriptaid, SAHA and oxamflatin are inhibitors for classes I and Ila/b HDACs (Blackwell et al., 2008; Chuang et al., 2009; Codd et al., 2009; Kuhn et al., 2009; Marks et al., 2003; Mukhopadhyay et al., 2006; Zhang and Dent, 2005). These significantly improved the cloning efficiency. On the other hand, APHA is an inhibitor of classes I and Ila/b HDACs but is greater than 10-fold more active against HDAC3 (class I) and HDAC6 (class Ilb) than the other HDACs (Blackwell et al., 2008; Mai et al., 2003). VPA is an inhibitor for classes I and Ila HDACs (Chuang et al., 2009). However, these two drugs did not improve the mouse cloning success rate (Ono et al., 2010). Sirtinol is an inhibitor of class III HDAC but its effect on cloning was very limited (Hirata et al., 2008). Thus, inhibition of class IIb HDACs (HDAC6 and 10, but most likely HDAC10) appears to be very important for improving the success rate in cloning mice (Table 1). It is known that the HDAC Ilb preferentially target not only nuclear histone deacetylase but also plays important roles in the regulation of heat shock protein (HSP)-mediated vascular

\section{TABLE 1}

\section{IMPROVEMENTS IN CLONING OUTCOME AND CHARACTERISTICS OF EACH HISTONE DEACETYLASE INHIBITOR (HDACi) USED}

\begin{tabular}{|c|c|c|c|c|c|c|c|c|}
\hline \multirow{2}{*}{$\begin{array}{l}\text { Class of } \\
\text { HDAC }\end{array}$} & \multirow[b]{2}{*}{ Type of HDAC } & \multicolumn{7}{|c|}{ Inhibitor } \\
\hline & & TSA & SCR & SAHA & $O x$ & APHA & VPA & SIRT \\
\hline Class I & HDAC 1,2 and 8 & (อ) & (○) & (?) & (C) & $\bigcirc$ & (อ) & $\times$ \\
\hline Class I & HDAC 3 & () & (อ) & () & () & () & () & $\times$ \\
\hline Class Ila & $\operatorname{HDAC} 4,5,7$ and 9 & () & (?) & () & () & 0 & () & $\times$ \\
\hline Class Illb & HDAC 6 & () & (อ) & () & () & (อ) & $\times$ & $\times$ \\
\hline Class Illb & HDAC 10 & () & (?) & (?) & () & 0 & $\times$ & $\times$ \\
\hline Class III & SIRT 1-7 & $\times$ & $\times$ & $\times$ & $x$ & $\times$ & $\times$ & () \\
\hline \multicolumn{2}{|c|}{ Improvement in cloning? } & YES & YES & YES & YES & NO & NO & Slight \\
\hline \multicolumn{2}{|c|}{ Reference No. } & 1 & 2 & 3 & 3 & 2 & 3 & 4 \\
\hline
\end{tabular}

Key: TSA, trichostatin A; SCR, scriptaid; SAHA, suberoylanilide hydroxamic acid; Ox, oxamflatin; VPA, valproic acid; APHA or aroyl pyrrolyl hydroxamide; SIRT, sirtinol; UP, unpublished observation; (), inhibit normally; $\bigcirc, 10$-fold lower; $\times$, no effect.

Reference no 1: Kishigami et al., 2006b; 2: Van Thuan et al., 2009; 3: Ono et al., 2010; 4: Hirata et al., 2008. 
endothelial growth factor receptors (Park et al., 2008). These other pathways could have negative effects on embryo development or on complete genomic reprogramming following SCNT.

\section{How does HDACi treatment enhance reprogramming?}

Although the underlying mechanism of how HDACi treatment improves cloning efficiency remains unknown, it is thought that it can induce hyperacetylation of the core histones, resulting in structural changes in chromatin that permit transcription and enhanced DNA demethylation of the somatic cell-derived genome after SCNT (Kishigami et al., 2006b), which is a necessary part of genetic reprogramming (Simonsson and Gurdon, 2004). In fact, several reports clearly showed that HDACi treatment improved histone acetylation (Wang et al., 2007; Yamanaka et al., 2009), nascent mRNA production (Van Thuan et al., 2009) and gene expression (Tsuji et al., 2009) in a manner similar to that in normally fertilized embryos.

However, how histone methylation is modified in TSA-treated cloned embryos is not completely understood. Bui et al. found that TSA treatment caused an increase in chromosome decondensation and nuclear volume in SCNT-generated embryos, similar to embryos produced by intracytoplasmic sperm injection (Bui et al., 2010). Histone acetylation was increased in parallel with chromosome decondensation. This was associated with a more effective formation of DNA replication complexes in treated embryos. Interestingly, the proportion of SCNT-generated embryos showing an asymmetric expression of nascent RNA between blastomeres was reduced in the TSA-treated group significantly compared with controls at the 2-cell stage. Those results suggest that the incomplete and inaccurate genome reprogramming of SCNT-generated embryos was improved by TSA treatment.

\section{Why do cloned embryos require HDACi treatment for better genomic reprogramming?}

In nature, the oocyte cytoplasm contains reprogramming mechanisms such as histone acetylation or DNA demethylation that convert the sperm and oocyte nuclei to a totipotent state (Feil, 2009; Mayer et al., 2000; Wang et al., 2007). However, it is not yet clear whether these reprogramming factors are sufficient to reprogram the somatic cell nucleus, because the potential reprogramming machinery of the oocyte cytoplasm is prepared for the receipt of a gametic nucleus, not a somatic cell nucleus. In general, it is considered that the incomplete reprogramming of somatic cell nuclei following SCNT arises from poor reprogramming in the oocyte. However, we now think that the oocyte cytoplasm might reprogram the somatic cell nucleus too strongly, or that the somatic cell nucleus is more sensitive to oocyte reprogramming factors than gametic cell nuclei. Therefore, by inhibiting a particular HDAC-especially class Illb-during reprogramming, the donor nuclei in our studies were possibly reprogrammed more correctly (Kishigami et al., 2006b; Van Thuan et al., 2009), resulting in a higher success rate for cloning.

\section{Combination of ntES cell approaches for mouse clon- ing}

We proposed previously that ntES techniques could be applied to the biological sciences as a novel investigative tool. Potential investigations could be made using only this technique and not with conventional iPS technology. For example, Li et al. and Eggan et al. generated ntES cells from the nucleus of a single olfactory sensory neuron and then demonstrated that the odorant receptor gene was reset by SCNT, not accompanied by genomic alterations (Eggan et al., 2004; Li et al., 2004). Similarly, monoclonal mice have been generated from ntES cells derived from lymphocyte nuclei indirectly using tetraploid complementation (Hochedlinger and Jaenisch, 2002). Thus, ntES cell techniques can be applied to the characterization of very rare cells in the body. However, here, we propose another application of ntES cells: they can be used for reproduction of offspring from infertile or dead animals by combination with NT or by injection of ntES cells into the blastocyst to form a chimera (Figs. 3,4) (Wakayama et al., 2005b).

\section{Producing offspring from individual mice}

The current success rate of generating cloned mice from adult somatic cell nuclei is very low, whereas the generation of cloned mice from ES cell nuclei is relatively high (Wakayama et al., 2005c; Wakayama et al., 1998). We have examined whether the success rate of cloning from somatic cells could be improved through the use of ntES cells established from the somatic cell

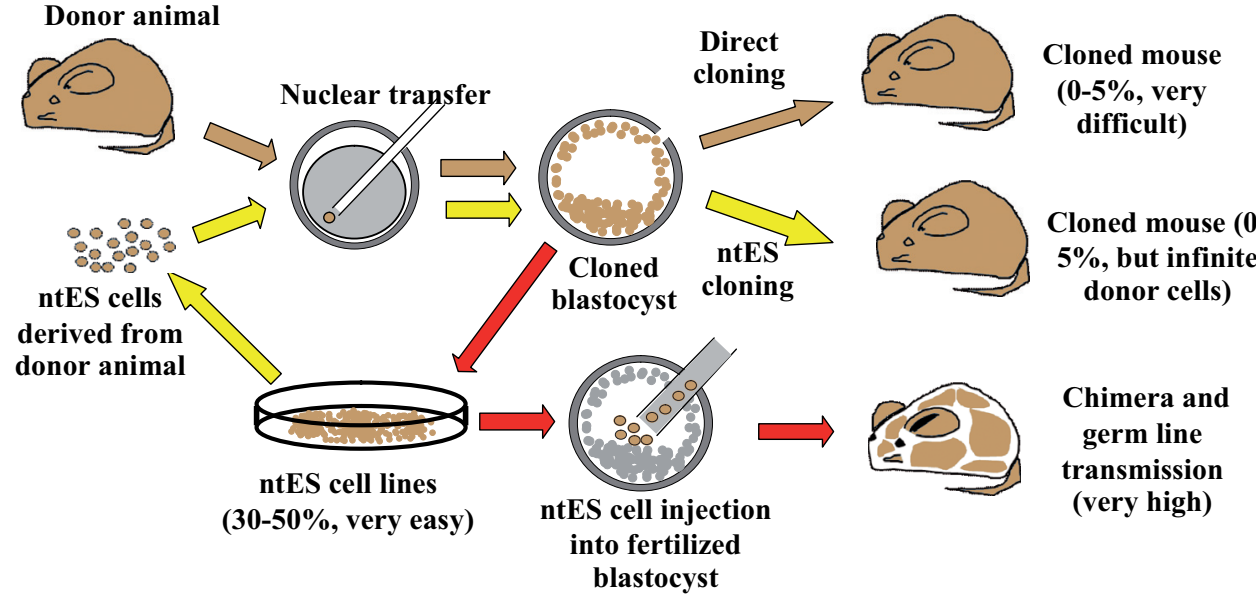

Fig. 3. Three different approaches to generate offspring from infertile, 'unclonable' or frozen dead mice. The blue arrow showed general nuclear transfer method (direct cloning). The success rate of mouse clone is 0 $5 \%$. The red arrow showed the establishment of ntES cell lines from cloned blastocysts and making chimera (for germ line transmission). Establish rate of ntES cell lines is very high (20-50\%) and most of cell lines can differentiate to germ cell of chimera. The yellow arrow showed serial nuclear transfer method (ntES cloning). The success rate of mouse clone is $0-5 \%$, same as direct cloning. However, donor cell became infinite. Therefore, you can repeat this experiment infinitely. 


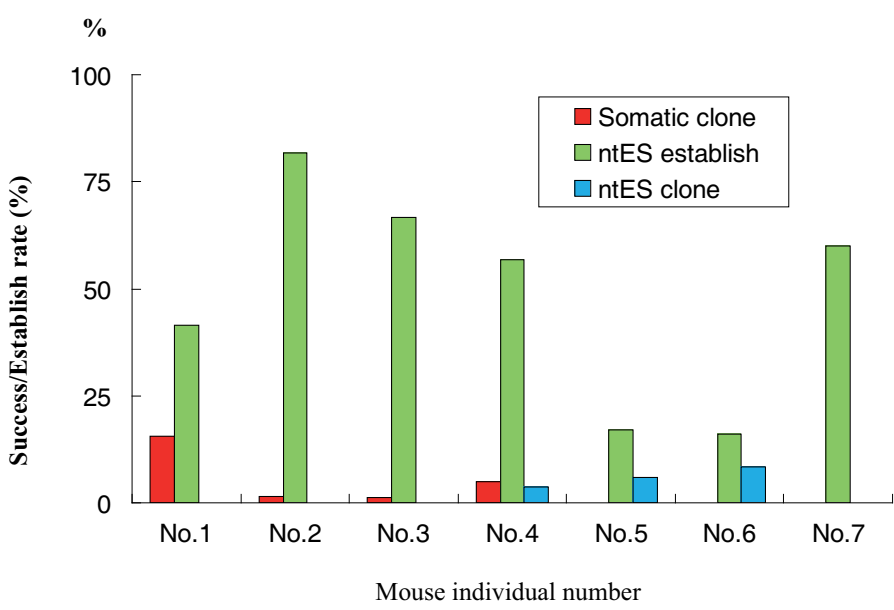

Fig. 4. Success rates of cloning mice and rate of establishing ntES cell lines in different individuals. In this experiment, seven mice were used as donors and cloned mice were obtained from four of them (Nos 1 to 4). The ntES cell lines were established from all donor mice at the same time with a very high success rate. Using a second round of nuclear transfer with ntES cells as the donors, cloned mice were obtained from two of the remaining three donor mice (Nos 5 and 6). Only one donor mouse (No. 7) failed to produce a cloned mouse by either somatic cell nuclear transfer or ntES cell cloning.

nuclei of the same individual (Wakayama et al., 2005b). Although we obtained many cloned mice, the overall success rate of cloning in this way was no better than when using somatic cell nuclei. Importantly, even when using TSA, the current success rate of somatic cell nuclear transfer is still low and in this study, we could obtain cloned mice from four individuals out of seven donor mice. The other three mice have never been cloned. However, we could establish several ntES cell lines from all individuals and healthy cloned mice were obtained from two of the remaining three individuals (Fig. 4) (Wakayama et al., 2005b). Therefore, although using ntES cells as nuclear donors does not ensure a better success rate for mouse cloning than that with somatic cells, we recommend the establishment of ntES cell lines at the same time to preserve and clone valuable individuals. These can be used as an unlimited source of donor nuclei for NT and can therefore complement conventional somatic cell NT cloning approaches (Wakayama et al., 2005b). Unfortunately, if difficulty is experienced in producing cloned mice from a donor cell, it is also experienced when attempting to produce cloned mice by a second round of NT from ntES cell nuclei (Wakayama et al., 2005a).

\section{Producing offspring from infertile mice}

The genetically modified mouse is a powerful tool for research in the fields of medicine and biology but they are often unhealthy and infertile. Overcoming this infertile phenotype is a challenge worth undertaking, as the ability to maintain such types of mutant mice as genetic resources would afford numerous advantages for research in human infertility and in the biology of reproduction. For this reason, we have tried to demonstrate that the ntES cell technology can be applied to generate offspring from such infertile mice. For example, senescent mice are often infertile and the cloning success rate decreases with age, making it almost impossible to produce cloned progeny directly from such mice. How- ever, we succeeded in establishing ntES cell lines from aged mice (nearly 3 years old) regardless of sex or strain. The cloned mice were obtained from these ntES cells by a second round of NT (Mizutani et al., 2008). We also achieved success using a mutant, hermaphroditic, sterile mouse found in our ICR mouse breeding colony (Wakayama et al., 2005a). Although the mutant mouse died accidentally soon after tail-tip biopsy and we failed to produce cloned mice from those cells, we could establish several $\mathrm{ntES}$ cell lines. Using those ntES cell lines, we generated chimeric mice by injecting them into normal embryos and finally one diploid chimeric male transmitted most of its mutant mouse genes to the next generation via the ntES cells. Thus, this technique is potentially applicable for the propagation of a variety of animals or important mutant genes, regardless of age or fertile potential.

\section{The possibility of resurrecting an extinct animal}

Cloning animals by SCNT provides an opportunity to preserve endangered mammalian species as when viable cells can be collected from frozen bodies, it is possible to generate cloned animals (Hoshino et al., 2009). However, the 'resurrection' of extinct species from permafrost (such as the woolly mammoth) is thought to be impractical, because no live cells will be available. On the other hand, it is known that 'dead' sperm from freezedrying treatments (Wakayama and Yanagimachi, 1998) or from a whole frozen body (Ogonuki et al., 2006) still possess the complete haploid genome, and when such sperm are injected into oocytes, the resulting embryos can develop to full-term healthy offspring. Recently, successful SCNT using freeze-dried cells was reported. Loi et al. generated cloned bovine blastocysts from freeze-dried somatic cells preserved for 3 years at room temperature (Loi et al., 2008). This report was the first to demonstrate that even freeze-dried somatic cells have developmental potential after NT, but the authors could not determine whether the blasto-

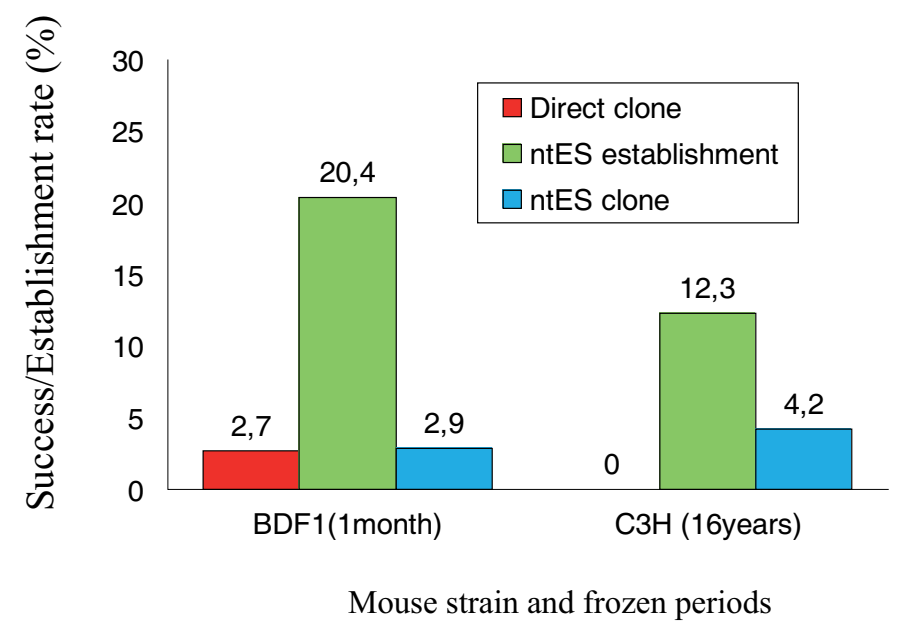

Fig. 5. Production of offspring from frozen dead mice. The outcomes for BDF1 mice frozen for 1 month and $\mathrm{C} 3 \mathrm{H}$ mice frozen for 16 years were compared between direct SCNT cloning, the rate of establishment of $n t E S$ cells from cloned blastocysts, and ntES cell cloning. For the longterm frozen mice, direct cloning failed, probably because these were an inbred 'unclonable' strain rather than because of the duration of storage. However, several ntES cell lines were established from both sets of tissues and many healthy cloned mice were obtained by successive rounds of NT using these cell lines. 
cysts were normal. On the other hand, we established ntES cell lines from freeze-dried mouse cells (Ono et al., 2008). Importantly, after chimera construction experiments, these ntES cell lines could contribute into all organs including germ cells, which suggests that the genomic integrity of somatic cells can be maintained after freeze-drying and that it is possible to produce offspring from such cells using SCNT.

We have also attempted to produce cloned mice from bodies kept frozen at $-20^{\circ} \mathrm{C}$ for up to 16 years without any cryoprotection. These conditions are similar to those of a frozen body recovered from permafrost. Although we could not produce cloned offspring from the somatic cells directly, several ntES cell lines were established from the cell nuclei of most organ cells, irrespective of the duration of preservation. Surprisingly, frozen brain was the best tissue for generating cloned embryos, even though fresh brain tissue has proven to be one of the most difficult sources of nuclei for the successful production of cloned mice (Mizutani et al., 2006; Yamazaki et al., 2001). Finally, healthy cloned mice were produced from these ntES cells by a second round of NT (Fig. 5) (Wakayama et al., 2008). Thus, these techniques could be used to resurrect animals or to maintain genome stocks from tissues that have been frozen for prolonged periods or even when no live cells are available.

\section{Perspectives}

The mouse is a most popular experimental animal and the advent of mouse cloning from adult-derived cells in 1998 marked a new departure in the study of key problems in cloning biology. Unfortunately, the success rate of SCNT cloning is still very low and the mechanisms involved in reprogramming the epigenome are not yet clear. Therefore, the SCNT method has been thought of as a 'black box approach' and inadequate to determine the detail of how genomic reprogramming occurs (Thuan et al., 2010). However, only the NT approach can reveal dynamic and global modifications in the epigenome without using genetic modification and can give important hints to the reprogramming mechanism. Moreover, the NT approach remains the only valid way to study biology, especially in generating offspring from a single cell or even from dead cell nuclei. The abnormalities seen in cloned animals pose a major obstacle for application but this could be resolved when the mechanisms of genomic reprogramming are better understood. We believe that the mechanisms of reprogramming will be clarified when cloning efficiency is improved through technical advances.

\section{References}

BLACKWELL, L., NORRIS, J., SUTO, C. M. and JANZEN, W. P. (2008). The use of diversity profiling to characterize chemical modulators of the histone deacetylases. Life Sci 82: 1050-1058.

BOIANI, M., ECKARDT, S., SCHOLER, H. R. and MCLAUGHLIN, K. J. (2002). Oct4 distribution and level in mouse clones: consequences for pluripotency. Genes Dev 16: 1209-1219.

BORTVIN, A., EGGAN, K., SKALETSKY, H., AKUTSU, H., BERRY, D. L., YANAGIMACHI, R., PAGE, D. C. and JAENISCH, R. (2003). Incomplete reactivation of Oct4-related genes in mouse embryos cloned from somatic nuclei. Development 130: 1673-1680.

BRAMBRINK, T., HOCHEDLINGER, K., BELL, G. and JAENISCH, R. (2006). ES cells derived from cloned and fertilized blastocysts are transcriptionally and functionally indistinguishable. Proc Natl Acad Sci USA 103: 933-938.

BUI, H. T., WAKAYAMA, S., KISHIGAMI, S., KIM, H. J., VAN THUAN, N. and WAKAYAMA, T. (2010). Effect of Trichostatin A on chromatin remodeling, histone modifications, DNA replication and transcriptional activity in cloned mouse embryos. Biol Reprod 83: 454-463.

CHUANG, D. M., LENG, Y., MARINOVA, Z., KIM, H. J. and CHIU, C. T. (2009) Multiple roles of HDAC inhibition in neurodegenerative conditions. Trends Neurosci 32: 591-601.

CIBELLI, J. B., STICE, S. L., GOLUEKE, P. J., KANE, J. J., JERRY, J., BLACKWELL, C., PONCE DE LEON, F. A. and ROBL, J. M. (1998). Transgenic bovine chimeric offspring produced from somatic cell-derived stem-like cells. Nat Biotechnol 16: 642-646.

CODD, R., BRAICH, N., LIU, J., SOE, C. Z. and PAKCHUNG, A. A. (2009). Zn(II)dependent histone deacetylase inhibitors: suberoylanilide hydroxamic acid and trichostatin A. Int J Biochem Cell Biol 41: 736-739.

COSTA-BORGES, N., SANTALO, J. and IBANEZ, E. (2010). Comparison between the Effects of Valproic Acid and Trichostatin A on the In vitro Development, Blastocyst Quality, and Full-Term Development of Mouse Somatic Cell Nuclear Transfer Embryos. Cell Reprogram 12: 437-446.

DAI, X., HAO, J., HOU, X. J., HAI, T., FAN, Y., YU, Y., ALICE, J., WANG, L. and ZHOU, Q. (2010). Somatic nucleus reprogramming is significantly improved by m-carboxycinnamic acid bishydroxamide (CBHA), a histone deacetylase inhibitor. J Biol Chem.

DEAN, W., SANTOS, F., STOJKOVIC, M., ZAKHARTCHENKO, V., WALTER, J., WOLF, E. and REIK, W. (2001). Conservation of methylation reprogramming in mammalian development: aberrant reprogramming in cloned embryos. Proc Natl Acad Sci USA 98: 13734-13738

EGGAN, K., BALDWIN, K., TACKETT, M., OSBORNE, J., GOGOS, J., CHESS, A., AXEL, R. and JAENISCH, R. (2004). Mice cloned from olfactory sensory neurons. Nature 428: 44-49.

ENRIGHT, B. P., KUBOTA, C., YANG, X. and TIAN, X. C. (2003). Epigenetic characteristics and development of embryos cloned from donor cells treated by trichostatin A or 5-aza-2'-deoxycytidine. Biol Reprod 69: 896-901.

FEIL, R. (2009). Epigenetic asymmetry in the zygote and mammalian development. Int J Dev Biol 53: 191-201.

GURVICH, N., BERMAN, M. G., WITTNER, B. S., GENTLEMAN, R. C., KLEIN, P. S. and GREEN, J. B. (2005). Association of valproate-induced teratogenesis with histone deacetylase inhibition in vivo. FASEB J 19: 1166-1168.

HIRATA, S., FUKASAWA, H., TAGAYA, H., SHODA, T., WAKAYAMA, T. and HOSHI, K. (2008). Effects of Sirtinol on Early Development of the Cloned Murine Embryos. Yamanashi medical Journal 23: 97-107.

HOCHEDLINGER, K. and JAENISCH, R. (2002). Monoclonal mice generated by nuclear transfer from mature B and T donor cells. Nature 415: 1035-1038.

HOSHINO, Y., HAYASHI, N., TANIGUCHI, S., KOBAYASHI, N., SAKAI, K., OTANI, T., IRITANI, A. and SAEKI, K. (2009). Resurrection of a bull by cloning from organs frozen without cryoprotectant in a -80 degrees $c$ freezer for a decade. PLos One 4: e4142.

HUANGFU, D., MAEHR, R., GUO, W., EIJKELENBOOM, A., SNITOW, M., CHEN A. E. and MELTON, D. A. (2008). Induction of pluripotent stem cells by defined factors is greatly improved by small-molecule compounds. Nat Biotechnol 26: 795-797.

IAGER, A. E., RAGINA, N. P., ROSS, P. J., BEYHAN, Z., CUNNIFF, K., RODRIGUEZ, R. M. and CIBELLI, J. B. (2008). Trichostatin A improves histone acetylation in bovine somatic cell nuclear transfer early embryos. Cloning Stem Cells 10: 371 379.

INOUE, K., OGONUKI, N., MOCHIDA, K., YAMAMOTO, Y., TAKANO, K., KOHDA, T., ISHINO, F. and OGURA, A. (2003). Effects of donor cell type and genotype on the efficiency of mouse somatic cell cloning. Biol Reprod 69: 1394-1400.

INOUE K, OGONUKI N, MEKADA K, YOSHIKI A, SADO T. and OGURA A. (2009). Sex-reversed somatic cell cloning in the mouse. J Reprod Dev. 55: 566-569.

INOUE K, KOHDA T, SUGIMOTO M, SADO T, OGONUKI N, MATOBA S, SHIURA $H$, IKEDA R, MOCHIDA K, FUJII T, SAWAI K, OTTE AP, TIAN XC, YANG $X$, ISHINO F, ABE K. and OGURA A. Impeding Xist expression from the active $X$ chromosome improves mouse somatic cell nuclear transfer. (2010). Science. 330: 496-499.

IWATANI, M., IKEGAMI, K., KREMENSKA, Y., HATTORI, N., TANAKA, S., YAGI, 
S. and SHIOTA, K. (2006). Dimethyl Sulfoxide (DMSO) Increases Expression of Dnmt3as and Affects Genome-wide DNA Methylation Profiles in Mouse Embryoid Body. Stem Cells 24: 2549-2566.

KANG, Y. K., KOO, D. B., PARK, J. S., CHOI, Y. H., CHUNG, A. S., LEE, K. K. and HAN, Y. M. (2001). Aberrant methylation of donor genome in cloned bovine embryos. Nat Genet 28: 173-177.

KAWASE, E., YAMAZAKI, Y., YAGI, T., YANAGIMACHI, R. and PEDERSEN, R. A. (2000). Mouse embryonic stem (ES) cell lines established from neuronal cellderived cloned blastocysts. Genesis 28: 156-163.

KISHIGAMI, S., BUI, H. T., WAKAYAMA, S., TOKUNAGA, K., VAN THUAN, N., HIKICHI, T., MIZUTANI, E., OHTA, H., SUETSUGU, R., SATA, T. et al. (2007). Successful mouse cloning of an outbred strain by trichostatin A treatment after somatic nuclear transfer. J Reprod Dev 53: 165-170.

KISHIGAMI, S., HIKICHI, T., VAN THUAN, N., OHTA, H., WAKAYAMA, S., BUI, H. T., MIZUTANI, E. and WAKAYAMA, T. (2006a). Normal specification of the extraembryonic lineage after somatic nuclear transfer. FEBS Lett 580: 18011806.

KISHIGAMI, S., MIZUTANI, E., OHTA, H., HIKICHI, T., THUAN, N. V., WAKAYAMA, S., BUI, H. T. and WAKAYAMA, T. (2006b). Significant improvement of mouse cloning technique by treatment with trichostatin $A$ after somatic nuclear transfer. Biochem Biophys Res Commun 340: 183-189.

KISHIGAMI, S., OHTA, H., MIZUTANI, E., WAKAYAMA, S., BUI, H. T., THUAN, N. V., HIKICHI, T., SUETSUGU, R. and WAKAYAMA, T. (2006c). Harmful or Not: Trichostatin A treatment of embryos generated by ICSI or ROSI. Central European Journal of Biology 1: 376-385.

KUHN, A. N., VAN SANTEN, M. A., SCHWIENHORST, A., URLAUB, H. and LUHRMANN, R. (2009). Stalling of spliceosome assembly at distinct stages by small-molecule inhibitors of protein acetylation and deacetylation. RNA 15: 153175.

LI, J., ISHII, T., FEINSTEIN, P. and MOMBAERTS, P. (2004). Odorant receptor gene choice is reset by nuclear transfer from mouse olfactory sensory neurons. Nature 428: 393-399.

LI, J., SVARCOVA, O., VILLEMOES, K., KRAGH, P. M., SCHMIDT, M., BOGH, I. B., ZHANG, Y., DU, Y., LIN, L., PURUP, S. et al. (2008). High in vitro development after somatic cell nuclear transfer and trichostatin A treatment of reconstructed porcine embryos. Theriogenology 70: 800-808.

LOI, P., MATSUKAWA, K., PTAK, G., CLINTON, M., FULKA, J., JR., NATHAN, Y. and ARAV, A. (2008). Freeze-dried somatic cells direct embryonic development after nuclear transfer. PLoS One 3: e2978.

MAI, A., MASSA, S., RAGNO, R., CERBARA, I., JESACHER, F., LOIDL, P. and BROSCH, G. (2003). 3-(4-Aroyl-1-methyl-1H-2-pyrrolyl)-N-hydroxy-2alkylamides as a new class of synthetic histone deacetylase inhibitors. 1. Design, synthesis, biological evaluation, and binding mode studies performed through three different docking procedures. J Med Chem 46: 512-524.

MARKS, P. A., MILLER, T. and RICHON, V. M. (2003). Histone deacetylases. Curr Opin Pharmacol 3: 344-351.

MAYER, W., NIVELEAU, A., WALTER, J., FUNDELE, R. and HAAF, T. (2000). Demethylation of the zygotic paternal genome. Nature 403: 501-502.

MENG, Q., POLGAR, Z., LIU, J. and DINNYES, A. (2009). Live birth of somatic cellcloned rabbits following trichostatin $A$ treatment and cotransfer of parthenogenetic embryos. Cloning Stem Cells 11: 203-208.

MIZUTANI, E., OHTA, H., KISHIGAMI, S., VAN THUAN, N., HIKICHI, T., WAKAYAMA, S., KOSAKA, M., SATO, E. and WAKAYAMA, T. (2006). Developmental ability of cloned embryos from neural stem cells. Reproduction 132: 849-857.

MIZUTANI, E., ONO, T., LI, C., MAKI-SUETSUGU, R. and WAKAYAMA, T. (2008). Propagation of senescent mice using nuclear transfer embryonic stem cell lines. Genesis 46: 478-483.

MUKHOPADHYAY, N. K., WEISBERG, E., GILCHRIST, D., BUENO, R., SUGARBAKER, D. J. and JAKLITSCH, M. T. (2006). Effectiveness of trichostatin $A$ as a potential candidate for anticancer therapy in non-small-cell lung cancer. Ann Thorac Surg 81: 1034-1042.

MUNSIE, M. J., MICHALSKA, A. E., O'BRIEN, C. M., TROUNSON, A. O., PERA, M. F. and MOUNTFORD, P. S. (2000). Isolation of pluripotent embryonic stem cells from reprogrammed adult mouse somatic cell nuclei. Curr Biol 10: 989992.
OGONUKI, N., INOUE, K., YAMAMOTO, Y., NOGUCHI, Y., TANEMURA, K., SUZUKI, O., NAKAYAMA, H., DOI, K., OHTOMO, Y., SATOH, M. et al. (2002). Early death of mice cloned from somatic cells. Nat Genet 30: 253-254.

OGONUKI, N., MOCHIDA, K., MIKI, H., INOUE, K., FRAY, M., IWAKI, T., MORIWAKI, K., OBATA, Y., MOROZUMI, K., YANAGIMACHI, R. et al. (2006). Spermatozoa and spermatids retrieved from frozen reproductive organs or frozen whole bodies of male mice can produce normal offspring. Proc Natl Acad Sci USA 103: 13098-13103.

OHGANE, J., WAKAYAMA, T., KOGO, Y., SENDA, S., HATTORI, N., TANAKA, S. YANAGIMACHI, R. and SHIOTA, K. (2001). DNA methylation variation in cloned mice. Genesis 30: 45-50.

ONO, T., LI, C., MIZUTANI, E., TERASHITA, Y., YAMAGATA, K. and WAKAYAMA T. (2010). Inhibition of Class Illb Histone Deacetylase Significantly Improves Cloning Efficiency in Mice. Biol Reprod. 83: 929-937.

ONO, T., MIZUTANI, E., LI, C. and WAKAYAMA, T. (2008). Nuclear transfer preserves the nuclear genome of freeze-dried mouse cells. J Reprod Dev 54: 486-491.

PARK, J. H., KIM, S. H., CHOI, M. C., LEE, J., OH, D. Y., IM, S. A., BANG, Y. J. and KIM, T. Y. (2008). Class II histone deacetylases play pivotal roles in heat shock protein 90-mediated proteasomal degradation of vascular endothelial growth factor receptors. Biochem Biophys Res Commun 368: 318-322.

RIDEOUT, W. M., 3RD, HOCHEDLINGER, K., KYBA, M., DALEY, G. Q. and JAENISCH, R. (2002). Correction of a genetic defect by nuclear transplantation and combined cell and gene therapy. Cell 109: 17-27.

RYBOUCHKIN, A., KATO, Y. and TSUNODA, Y. (2006). Role of histone acetylation in reprogramming of somatic nuclei following nuclear transfer. Biol Reprod 74: 1083-1089.

SANTOS, F., ZAKHARTCHENKO, V., STOJKOVIC, M., PETERS, A., JENUWEIN, T., WOLF, E., REIK, W. and DEAN, W. (2003). Epigenetic marking correlates with developmental potential in cloned bovine preimplantation embryos. Curr Biol 13: 1116-1121.

SHI, L. H., MIAO, Y. L., OUYANG, Y. C., HUANG, J. C., LEI, Z. L., YANG, J. W. HAN, Z. M., SONG, X. F., SUN, Q. Y. and CHEN, D. Y. (2008). Trichostatin A (TSA) improves the development of rabbit-rabbit intraspecies cloned embryos, but not rabbit-human interspecies cloned embryos. Dev Dyn 237: 640-648.

SIMONSSON, S. and GURDON, J. (2004). DNA demethylation is necessary for the epigenetic reprogramming of somatic cell nuclei. Nat Cell Biol 6: 984-990.

STERTHAUS, O., SKOCZYLAS, E., DE GEYTER, C., BURKI, K. and LEDERMANN B. (2009). Evaluation of in vitro cultured rat oocytes, from different strains, by spindle morphology and maturation-promoting-factor activity combined with nuclear-transfer experiments. Cloning Stem Cells 11: 463-472.

SU, G. H., SOHN, T. A., RYU, B. and KERN, S. E. (2000). A novel histone deacetylase inhibitor identified by high-throughput transcriptional screening of a compound library. Cancer Res 60: 3137-3142.

SVENSSON, K., MATTSSON, R., JAMES, T. C., WENTZEL, P., PILARTZ, M., MACLAUGHLIN, J., MILLER, S. J., OLSSON, T., ERIKSSON, U. J. and OHLSSON, R. (1998). The paternal allele of the H19 gene is progressively silenced during early mouse development: the acetylation status of histones may be involved in the generation of variegated expression patterns. Development 125: 61-69.

TABAR, V., TOMISHIMA, M., PANAGIOTAKOS, G., WAKAYAMA, S., MENON, J., CHAN, B., MIZUTANI, E., AL-SHAMY, G., OHTA, H., WAKAYAMA, T. et al. (2008). Therapeutic cloning in individual parkinsonian mice. Nat Med 14: 379381 .

TAMASHIRO, K. L., WAKAYAMA, T., AKUTSU, H., YAMAZAKI, Y., LACHEY, J. L., WORTMAN, M. D., SEELEY, R. J., D'ALESSIO, D. A., WOODS, S. C., YANAGIMACHI, R. et al. (2002). Cloned mice have an obese phenotype not transmitted to their offspring. Nat Med 8: 262-267.

TAMASHIRO, K. L., WAKAYAMA, T., BLANCHARD, R. J., BLANCHARD, D. C. and YANAGIMACHI, R. (2000). Postnatal growth and behavioral development of mice cloned from adult cumulus cells. Biol Reprod 63: 328-334.

TANAKA, S., ODA, M., TOYOSHIMA, Y., WAKAYAMA, T., TANAKA, M., YOSHIDA N., HATTORI, N., OHGANE, J., YANAGIMACHI, R. and SHIOTA, K. (2001). Placentomegaly in cloned mouse concepti caused by expansion of the spongiotrophoblast layer. Biol Reprod 65: 1813-1821.

THUAN, N. V., KISHIGAMI, S. and WAKAYAMA, T. (2010). How to improve the 


\section{S. Wakayama and T. Wakayama}

success rate of mouse cloning technology. J Reprod Dev 56: 20-30.

TSUJI, Y., KATO, Y. and TSUNODA, Y. (2009). The developmental potential of mouse somatic cell nuclear-transferred oocytes treated with trichostatin $A$ and 5-aza-2'-deoxycytidine. Zygote 17: 109-115.

VAN THUAN, N., BUI, H. T., KIM, J. H., HIKICHI, T., WAKAYAMA, S., KISHIGAMI, S., MIZUTANI, E. and WAKAYAMA, T. (2009). The histone deacetylase inhibitor scriptaid enhances nascent mRNA production and rescues full-term development in cloned inbred mice. Reproduction 138: 309-317.

WAKAYAMA, S., JAKT, M. L., SUZUKI, M., ARAKI, R., HIKICHI, T., KISHIGAMI, S., OHTA, H., VAN THUAN, N., MIZUTANI, E., SAKAIDE, Y. et al. (2006). Equivalency of nuclear transfer-derived embryonic stem cells to those derived from fertilized mouse blastocysts. Stem Cells 24: 2023-2033.

WAKAYAMA, S., KISHIGAMI, S., VAN THUAN, N., OHTA, H., HIKICHI, T. MIZUTANI, E., YANAGIMACHI, R. and WAKAYAMA, T. (2005a). Propagation of an infertile hermaphrodite mouse lacking germ cells by using nuclear transfer and embryonic stem cell technology. Proc Natl Acad Sci USA 102: 29-33.

WAKAYAMA, S., MIZUTANI, E., KISHIGAMI, S., THUAN, N. V., OHTA, H., HIKICHI, T., BUI, H. T., MIYAKE, M. and WAKAYAMA, T. (2005b). Mice cloned by nuclear transfer from somatic and ntES cells derived from the same individuals. J Reprod Dev 51: 765-772.

WAKAYAMA, S., OHTA, H., HIKICHI, T., MIZUTANI, E., IWAKI, T., KANAGAWA, $O$. and WAKAYAMA, T. (2008). Production of healthy cloned mice from bodies frozen at -20 degrees $C$ for 16 years. Proc Natl Acad SciUSA 105: 17318-17322.

WAKAYAMA, S., OHTA, H., KISHIGAMI, S., THUAN, N. V., HIKICHI, T., MIZUTANI, E., MIYAKE, M. and WAKAYAMA, T. (2005c). Establishment of male and female nuclear transfer embryonic stem cell lines from different mouse strains and tissues. Biol Reprod 72: 932-936.

WAKAYAMA, T. (2007). Production of cloned mice and ES cells from adult somatic cells by nuclear transfer: how to improve cloning efficiency? J Reprod Dev 53: 13-26.

WAKAYAMA, T., PERRY, A. C., ZUCCOTTI, M., JOHNSON, K. R. and YANAGIMACHI, R. (1998). Full-term development of mice from enucleated oocytes injected with cumulus cell nuclei. Nature 394: 369-374.

WAKAYAMA, T., TABAR, V., RODRIGUEZ, I., PERRY, A. C., STUDER, L. and MOMBAERTS, P. (2001). Differentiation of embryonic stem cell lines generated from adult somatic cells by nuclear transfer. Science 292: 740-743.

WAKAYAMA, T. and YANAGIMACHI, R. (1998). Development of normal mice from oocytes injected with freeze-dried spermatozoa. Nat Biotechnol 16: 639-641.

WAKAYAMA, T. and YANAGIMACHI, R. (1999). Cloning of male mice from adult tail-tip cells. Nat Genet 22: 127-128.

WAKAYAMA, T. and YANAGIMACHI, R. (2001a). Effect of cytokinesis inhibitors DMSO and the timing of oocyte activation on mouse cloning using cumulus cell nuclei. Reproduction 122: 49-60.

WAKAYAMA, T. and YANAGIMACHI, R. (2001b). Mouse cloning with nucleus donor cells of different age and type. Mol Reprod Dev 58: 376-383.

WANG, F., KOU, Z., ZHANG, Y. and GAO, S. (2007). Dynamic reprogramming of histone acetylation and methylation in the first cell cycle of cloned mouse embryos. Biol Reprod 77: 1007-1016.

WILMUT, I., SCHNIEKE, A. E., MCWHIR, J., KIND, A. J. and CAMPBELL, K. H. (1997). Viable offspring derived from fetal and adult mammalian cells. Nature 385: 810-813.

WU, X., LI, Y., LI, G. P., YANG, D., YUE, Y., WANG, L., LI, K., XIN, P., BOU, S. and $\mathrm{YU}, \mathrm{H}$. (2008). Trichostatin A improved epigenetic modifications of transfected cells but did not improve subsequent cloned embryo development. Anim Biotechnol 19: 211-224.

YAMANAKA, K. I., SUGIMURA, S., WAKAI, T., KAWAHARA, M. and SATO, E. (2009). Acetylation Level of Histone H3 in Early Embryonic Stages Affects Subsequent Development of Miniature Pig Somatic Cell Nuclear Transfer Embryos. J Reprod Dev. 55: 299-304.

YAMAZAKI, Y., MAKINO, H., HAMAGUCHI-HAMADA, K., HAMADA, S., SUGINO, H., KAWASE, E., MIYATA, T., OGAWA, M., YANAGIMACHI, R. and YAGI, T. (2001). Assessment of the developmental totipotency of neural cells in the cerebral cortex of mouse embryo by nuclear transfer. Proc Natl Acad Sci USA 98: $14022-14026$

ZHANG, K. and DENT, S. Y. (2005). Histone modifying enzymes and cancer: going beyond histones. J Cell Biochem 96: 1137-1148.

ZHAO, J., ROSS, J. W., HAO, Y., SPATE, L. D., WALTERS, E. M., SAMUEL, M. S. RIEKE, A., MURPHY, C. N. and PRATHER, R. S. (2009). Significant improvement in cloning efficiency of an inbred miniature pig by histone deacetylase inhibitor treatment after somatic cell nuclear transfer. Biol Reprod 81: 525-530. 


\section{Further Related Reading, published previously in the Int. J. Dev. Biol.}

See our recent Special Issue Placenta edited by Joan S. Hunt and Kent L. Thornburg at: http://www.ijdb.ehu.es/web/contents.php?vol=54\&issue=2-3

Identification and gastrointestinal expression of Xenopus laevis FoxF2

Valérie A. McLin, Rina Shah, Neekita P. Desai and Milan Jamrich

Int. J. Dev. Biol. (2010) 54: 919-924

Early mammalian embryo: my love. An interview with Andrzej K. Tarkowski Marek Maleszewski and Andrzej K. Tarkowski

Int. J. Dev. Biol. (2008) 52: 163-169

Experimental embryology of mammals at the Jastrzebiec Institute of Genetics and Animal Breeding Jolanta Karasiewicz and Jacek Andrzej Modlinski

Int. J. Dev. Biol. (2008) 52: 157-161

Cloning, expression and functional study of translation elongation factor 2 (EF-2) in zebrafish Shu-hong Zhang, Ji-hua Yao, Huai-dong Song, Lu Wang and Jing-lun Xue Int. J. Dev. Biol. (2006) 50: 399-403

Isolation and growth factor inducibility of the Xenopus laevis Lmx1b gene.

Caroline E Haldin, Sarjit Nijjar, Karine Massé, Mark W Barnett and Elizabeth A Jones

Int. J. Dev. Biol. (2003) 47: 253-262

The case of the midwife scientist.

E Simpson

Int. J. Dev. Biol. (2001) 45: 513-518

A history of mammalian embryological research.

$\mathrm{H}$ Alexandre

Int. J. Dev. Biol. (2001) 45: 457-467

Developmental expression of H3.3A variant histone mRNA in mouse.

L A López-Fernández, D M López-Alañón, V Castañeda, D B Krimer and J del Mazo

Int. J. Dev. Biol. (1997) 41: 699-703

An mRNA differential display strategy for cloning genes expressed during mouse gonad development.

K Nordqvist and V Töhönen

Int. J. Dev. Biol. (1997) 41: 627-638

What can be learned from intermediate filament gene regulation in the mouse embryo.

P Duprey and D Paulin

Int. J. Dev. Biol. (1995) 39: 443-457

5 yr ISI Impact Factor $(2009)=3.253$
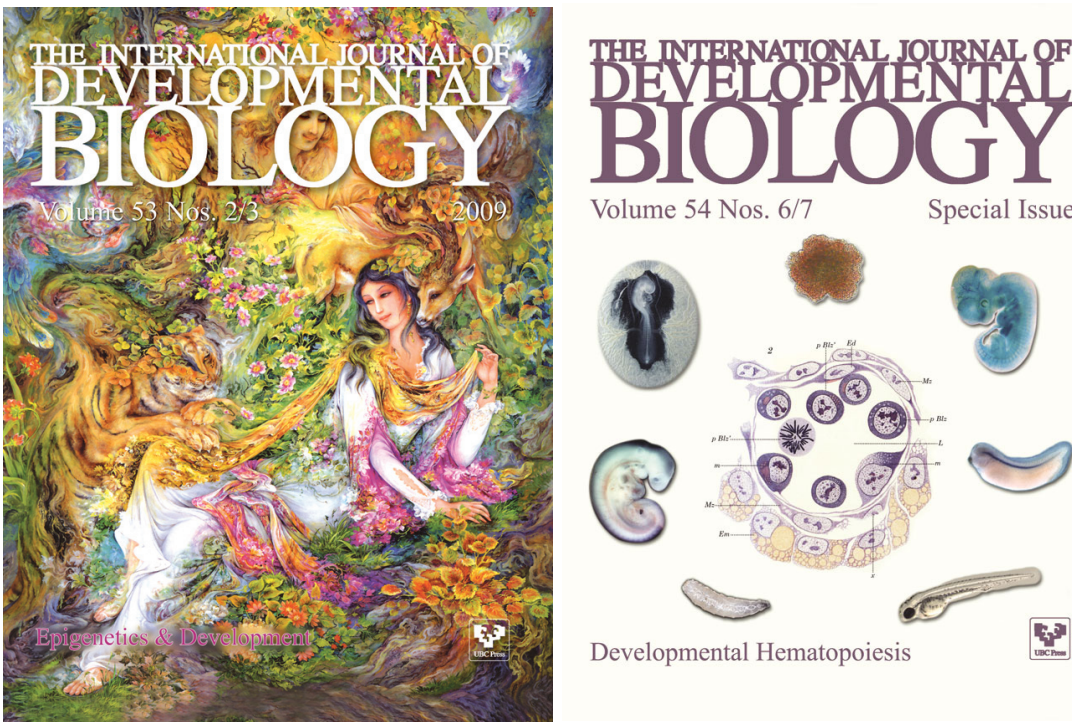

Volume 54 Nos. $6 / 7$

Special Issue
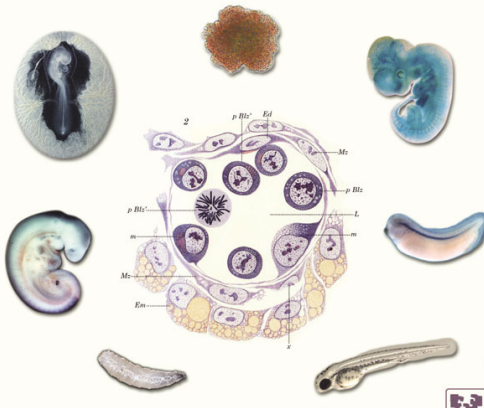

Developmental Hematopoiesis

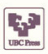

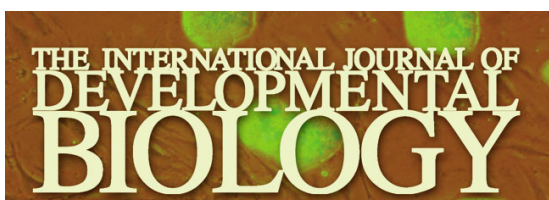

Volume 54 Nos. 11/12

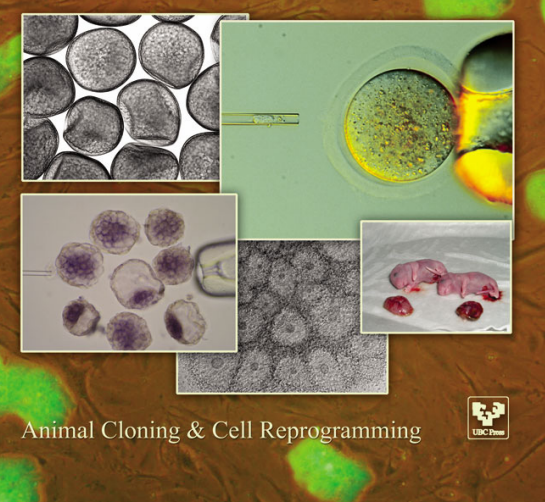

